Crop Breeding and Applied Biotechnology 14: 251-255, 2014

Brazilian Society of Plant Breeding. Printed in Brazil

NOTE

http://dx.doi.org/10.1590/1984-70332014v14n4n39

\title{
Chromosome duplication in Lolium multiflorum Lam.
}

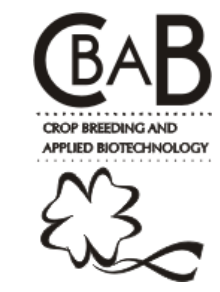

Roselaine Cristina Pereira ${ }^{1}$, Marco Túlio Mendes Ferreira ${ }^{1}$, Lisete Chamma Davide ${ }^{1}$, Moacir Pasqual ${ }^{2}$, Andréa Mittelmann ${ }^{3}$ and Vânia Helena Techio ${ }^{1^{*}}$

Received 4 August 2013

Accepted 8 August 2014

\begin{abstract}
Artificial chromosome duplication of diploid genotypes of Lolium multiflorum $(2 n=2 x=14)$ is worthy to breeding, and aims to increase the expression of traits with agronomic interest. The purpose of this study was to obtain polyploid plants of $\mathrm{L}$. multiflorum from local diploid populations in order to exploit adaptation and future verification of the effects of polyploidy in agronomic traits. Seedlings were immersed in different colchicine solutions for an exposure time of $3 \mathrm{~h}$ and $24 \mathrm{~h}$. Ploidy determination was made by the DNA content and certified by chromosomes counts. The plants confirmed as tetraploids were placed in a greenhouse, and, at flowering, pollen viability was evaluated, and seeds were harvested to assess the stability of the progenies. The percentage of polyploids obtained was 20\%. Pollen viability of the tetraploids generated ranged from $58 \%$ to $69 \%$. The tetraploid plants obtained in the experiment generated 164 progenies, of which 109 presented DNA content compatible with the tetraploid level, showing stability of chromosome duplication in the filial generation.
\end{abstract}

Key words: Polyploidization, tetraploid, forage grass, plant breeding.

\section{INTRODUCTION}

The production of polyploid plants has been one of the objectives of breeding programs for the purpose of obtaining differentiated genotypes in order to maximize traits of agronomic interest. Among its advantages, polyploidization allows broadening the genetic base, restoring the fertility of interspecific hybrids, obtaining breeding lines in a short time, and making crosses viable when genotypes are involved with differences in ploidy (Barbosa et al. 2007, Campos et al. 2009, Ishigaki et al. 2009, Souza-Kaneshima et al. 2010).

Polyploid plants may occur naturally, arising from some cytological mechanisms, such as formation of unreduced gametes, but they may be obtained synthetically by the induction of chromosome duplication of somatic cells. This procedure is possible by means of interference in the cell cycle, using antimitotic substances or thermal shocks. It affects the organization/polymerization, or causes rupture of the microtubules, which inhibits separation of the chromosomes, and results in the formation of cells with a duplicated chromosome complement (Dhooge et al. 2011).
In forage plants, as well as in other species, colchicine has been the antimitotic substance most used for inducing polyploidy (Barbosa et al. 2007, Campos et al. 2009, Ishigaki et al. 2009, Quesenberry et al. 2010, Souza-Kaneshima et al. 2010).

In Lolium, chromosome doubling was first achieved by Meyers in 1939, and the first tetraploid cultivar was released in 1950 (Humphreys 2010). After the development of flow cytometry, the examination of treated plants and their progeny for ploidy was fastened. Many cultivars were released internationally, and some of these have been recently introduced in Brazil. The attempts to obtain polyploids aim at expanding their potential as a forage crop, especially through enhancement of traits of agronomic interest, such as increases in forage yield and quality. Furthermore, colchicine has been used to obtain polyploids of $L$. perenne $\mathrm{x}$ Festuca arundinacea and $L$. perenne $\mathrm{x} L$. multiflorum hybrids (Thomas and Humphreys 1991, Jones and Humphreys 1993, Pasakinskiene 2000, Nair 2004).

Several comparisons have been made between diploid and tetraploid ryegrasses, and the general conclusion is that

\footnotetext{
${ }^{1}$ Federal University of Lavras (UFLA), Department of Biology, P.O. Box 3037, 37.200-000, Lavras, Minas Gerais, Brazil. *E-mail: vhtechio@gmail.com

${ }^{2}$ UFLA, Department of Agricuture

${ }^{3}$ Embrapa Dairy Cattle/Embrapa Temperate Agriculture, P.O. Box 403, 96.010-971, Pelotas, Rio Grande do Sul, Brazil
} 
there is some yield advantage of the tetraploids, especially in short-lived species of the Lolium genus. However, tetraploid characteristics depend very much on diploid origins (Humphreys 2010). Results for forage quality and disease resistance are variable as well.

Castro et al. (2003) carried out a study with L. multiflorum plants collected in Brazil, obtained from treatment of seeds with a 0.2 and $0.4 \%$ colchicine solution in order to analyze the mutagenic effects of colchicine. The authors observed significant effects in certain agronomic traits; however, it was also observed changes in allele frequency and pronounced mutagenic effects in the plants under evaluation. Besides this study, there are no others regarding polyploids in $L$. multiflorum genotypes naturalized in the country.

Thus, determination of a practical methodology for obtaining tetraploid plants using adapted genotypes is of great interest for generating tetraploid genotypes for commercial use, and for the future verification of the effects of polyploidy in agronomic traits. The purpose of this study was to obtain polyploid plants of $L$. multiflorum from local diploid populations using colchicine as a chromosome duplication inducing agent.

\section{MATERIAL AND METHODS}

Chromosome duplication was induced in diploid seedlings of L. multiflorum $(2 \mathrm{n}=2 \mathrm{x}=14)$, genotype LOL 161, derived from the Forage Plant Active Germplasm Bank of Embrapa Dairy Cattle, Juiz de Fora, Minas Gerais, Brazil. The option for performing the tests with an explant donat- ing genotype (seedling) was based on previous germination tests and tolerance to the toxic effects of colchicine used in the protocols for inducing chromosome duplication. In addition, considering that the genotypes, as well as the type of explant, may provide differentiated results in response to the treatments for chromosome duplication, the use of one genotype in all the treatments leads to uniform analysis regarding a genotypic variable. Moreover, it hinders interpretations of results based on interactions with the environment and treatment conditions, favoring the definition and standardization of the methodology.

The explants were obtained from germination of seeds in vivo. To that end, seeds were placed for germination in a germination chamber (BOD) at a temperature of $15^{\circ} \mathrm{C}$ for 15-20 days. After that, the whole explants (seedlings) were immersed in colchicine according to the concentration and exposure times presented in Table 1. The explants were also kept in a germination chamber (BOD) at a constant temperature of $15{ }^{\circ} \mathrm{C}$. After the exposure period, the explants were washed in water and planted in pots containing substrate, which were kept in controlled temperature conditions (15 $\left.{ }^{0} \mathrm{C}\right)$. Four replications were evaluated, with 24 seedlings/ replication/treatment.

\section{DNA content and chromosome number}

Determination of DNA content of plants obtained from seedlings subjected to chromosome duplication was performed by the flow cytometry technique, according to the protocol of Dolezel et al. (1997). Leaf tissue samples (70 $\mathrm{mg}$ ) of L. multiflorum and of Vicia faba (standard reference

Table 1. Treatments used for chromosome duplication in L. multiflorum Lam.

\begin{tabular}{lcc}
\hline Treatment & Concentration (\%) & Exposure time (h) \\
\hline Colchicine & 0.1 & $1 \mathrm{~h} 30 \mathrm{~min}$ \\
Colchicine & $0.1 ; 0.25$ and 0.50 & $3 \mathrm{~h}$ \\
Colchicine & $0.1 ; 0.25$ and 0.50 & $24 \mathrm{~h}$ \\
Colchicine $+1 \%$ DMSO & $0.1 ; 0.25$ and 0.50 & $24 \mathrm{~h}$ \\
\hline
\end{tabular}

Table 2. Percentage of survival and of tetraploid plants of Lolium multiflorum in vivo treatments with colchicine for inducing chromosome duplication

\begin{tabular}{lccc}
\hline Treatment & Time $(\mathrm{h})$ & Survival $(\%)$ & Tetraploids $(\%)$ \\
\hline $0.1 \%$ colchicine & $1 \mathrm{~h} 30$ & 23 & - \\
$0.1 \%$ colchicine & 3 & 80 & 30 \\
$0.25 \%$ colchicine & 3 & 30 & - \\
$0.5 \%$ colchicine & 3 & 30 & - \\
$0.1 \%$ colchicine & 24 & 33 & - \\
$0.25 \%$ colchicine & 24 & 37 & - \\
$0.5 \%$ colchicine & 24 & 75 & 10 \\
$0.1 \%$ colchicine $+1 \%$ DMSO & 24 & 34 & 24 \\
$0.25 \%$ colchicine $+1 \%$ DMSO & 24 & 32 \\
$0.5 \%$ colchicine+ $1 \%$ DMSO & 24 & 27 \\
\hline
\end{tabular}


plant) were ground up in a Petri dish containing $1 \mathrm{~mL}$ of cold LB01 buffer for nuclei release. The nuclear suspension was filtered through a $50 \mu \mathrm{m}$ mesh and stained with $25 \mu \mathrm{L}$ of Propidium Iodide. For each sample, ten thousand nuclei were analyzed using a logarithmic scale. Analysis was made on the FACSCalibur Cytometer (Becton Dickinson); the histograms were obtained with the Cell Quest software and statistically analyzed on the WinMDI 2.8 software.

Chromosome duplication was also verified by means of chromosome counts. The number of chromosomes was determined by evaluation of meristematic cells obtained from root tips pre-treated with water cooled for $24 \mathrm{~h}$, and fixed in Carnoy (ethyl alcohol:acetic acid, 3:1). The slides were prepared by the squash technique and stained with Giemsa 3\% for 5 minutes.

The plants effectively confirmed as tetraploids were placed in a greenhouse. In the flowering period, inflorescences were collected to verify pollen viability, and seeds were collected for evaluation of the stability of the progenies in regard to chromosome number and DNA content, following the same procedures described above. Viability of the pollen was determined by means of staining tests with $1 \%$ acetocarmine.

\section{RESULTS AND DISCUSSION}

The survival percentage of plants ranged from $23 \%$ (colchicine $0.1 \%$ for $1 \mathrm{~h} 30 \mathrm{~min}$ ) to $80 \%$ (colchicine $0.1 \%$ for $3 \mathrm{~h}$ ), and from $30 \%$ (colchicine $0.1 \%$ ) to $75 \%$ (colchicine $0.1 \%$ with $1 \%$ of DMSO - dimethyl sulfoxide), for exposure period of $24 \mathrm{~h}$ (Table 2).

The percentage of polyploids obtained among the surviving plants was $10 \%, 27 \%, 24 \%$ and $18 \%$ with the colchicine treatments at $0.25 \%, 0.5 \%+\mathrm{DMSO}, 0.25 \%+\mathrm{DMSO}$ and $0.1 \%+$ DMSO, respectively (Table 2 ). Results show that the addition of DMSO to colchicine favors chromosome duplication in annual ryegrass plants. The efficiency of the duplication procedure was observed for four treatments. Of these, the treatment that provided the best results used colchicine $0.5 \%+1 \%$ of DMSO for $24 \mathrm{~h}$, and allowed $27 \%$ regeneration of plants with a duplicated chromosome number.

Quantification of DNA by flow cytometry and chromosome counts showed that the tetraploid plants presented, on average, $12.05 \mathrm{pg}$ of DNA and 28 chromosomes (Figures 1 and 2).

Pollen viability of the tetraploid plants ranged from $58 \%$ to $69 \%$. Tetraploid plants, obtained from the treatment of colchicine $0.5 \%$ + DMSO $1 \%$ for $24 \mathrm{~h}$, flowered normally, produced viable pollen grains, but did not produce seeds.

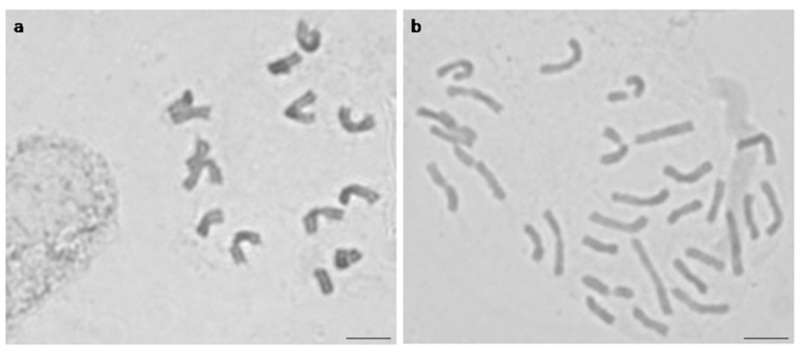

Figure 1. Mitotic metaphases of diploid (a- $2 n=2 x=14$ ) and artificial tetraploid ( $\mathrm{b}-2 \mathrm{n}=4 \mathrm{x}=28$ ) of L. multiflorum. Bar $=10 \mu \mathrm{m}$.

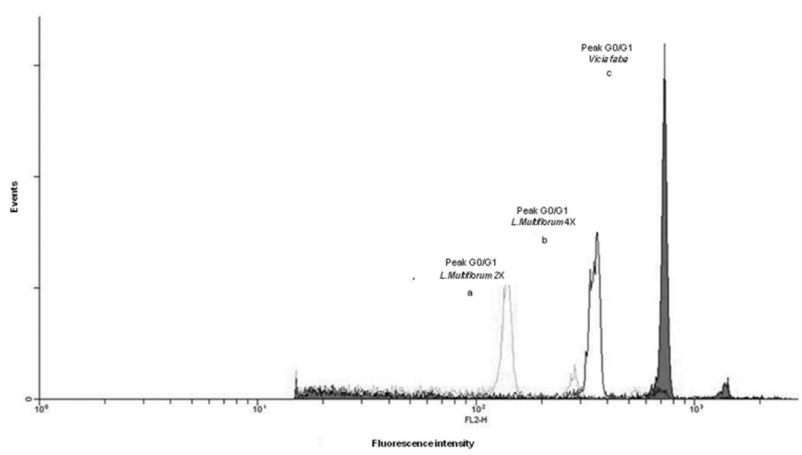

Figure 2. Nuclear DNA content in L. multiflorum plants: diploid $6.1 \mathrm{pg}$ (a); tetraploid $12.05 \mathrm{pg}$ (b), and for the standard of reference Vicia faba $26.09 \mathrm{pg}$ (c). The $\mathrm{X}$ axis represents the relative intensity of fluorescence, and the $\mathrm{Y}$ axis represents the number of nuclei evaluated.

Studies by Nunes et al. (2012) with genotypes of Lolium multiflorum, including two tetraploids, showed higher rates (above $90 \%$ ) of pollen viability. The authors suggested that the high rate of functional pollen in these genotypes may be associated with meiotic regularity and regular collection timings (8:30 a.m. to 10:00 a.m.) when anther dehiscence begins, implying that viability reaches its maximum.

The tetraploid plants obtained with the other treatments produced viable seeds, which generated 164 progenies, of which 84 derived from the treatment with colchicine $0.1 \%+$ DMSO $1 \%$, and 80 derived from the treatment with colchicine $0.25 \%+$ DMSO $1 \%$. Of these progenies, 109 presented DNA content compatible with the tetraploid level, showing stability of chromosome duplication in the filial generation.

The survival rate of plants observed in different treatments and times of exposure to colchicine shows the ability of this genotype of $L$. multiflorum in circumventing the toxic effect of this alkaloid in variable degrees of tolerance (Table 2).

The polyploiding effect of colchicine in L. multiflorum was obtained with $24 \mathrm{~h}$ exposure. Contrary to the results obtained by Nair (2004) and Pasakinskiene (2000), who 
obtained polyploid in L. perenne and hybrids of L. perenne $\mathrm{x}$ Festuca arundinaceae using colchicine for $3 \mathrm{~h}$, in this study, $1 \mathrm{~h} 30 \mathrm{~min}$ and $3 \mathrm{~h}$ exposures were insufficient for affecting organization of the microtubules and inducing the formation of polyploidy cells.

Variation in time of exposure to colchicine was also observed in the induction of chromosomal duplication of Brachiaria (Simioni and Valle 2009, Ishigaki et al. 2009, Timbó et al. 2014). The time of exposure to colchicine used was $48 \mathrm{~h}$ (Simioni and Valle 2009) and 2 and $3 \mathrm{~h}$ (Ishigaki et al. 2009, Timbó et al. 2014).

The results obtained for L. multiflorum show that the seedlings constitute an explant adequate for inducing chromosome duplication under the conditions tested, and that the addition of $1 \%$ of DMSO to the colchicine solution maximized, obtaining tetraploids. The DMSO increase cell permeability, allowing greater absorption of the substance, and consequently, strengthens the action of the antimitotic agent and the polyploidization rates (Hamill et al. 1992, Allum et al. 2007, Greplova et al. 2009). There are studies which state that the use of colchicine solution with DMSO reduces the survival rate of treated explants; however, it increases the survival rate of the polyploids obtained (Hamil et al. 1992), coinciding with the results observed in this study. Moreover, it was observed that for the $L$. multiflorum genotype evaluated, there was an increase in the rate of tetraploids related to the increase in colchicine concentration, which does not always occur, due to the increase of toxicity, as observed in Brachiaria (Pinheiro et al. 2000) and in the genotypes of Lolium perenne evaluated by Nair (2004).

In Brachiaria and Pennisetum, seedlings were successfully used for chromosome duplication. In Brachiaria, the authors obtained 31.3\% (Ishigaki et al. 2009) and 12.5\% (Timbó et al. 2014). In Pennisetum, Campos et al. (2009) and Barbosa et al. (2007) obtained $8.5 \%$ and $19.5 \%$ of hexaploids, respectively.

Colchicine concentrations of 0.1 and $0.25 \%$, with $1 \%$ of DMSO, produced 21 tetraploid plants, which generated viable pollen grains and seeds. From these, 164 progenies were obtained, of which 66\% (109) showed stability in relation to the ploidy level when evaluated after the establishment of the plants in a greenhouse. This monitoring of the polyploids in the subsequent generations is important for observing possible late effects of the colchicine, especially regarding the genetic and phenotypic stability of the individuals.

\section{ACKNOWLEDGEMENTS}

To the Fundação de Amparo à Pesquisa do Estado de Minas Gerais (FAPEMIG); Coordenação de Aperfeiçoamento de Pessoal de Nível Superior (CAPES); and to the Conselho Nacional de Desenvolvimento Científico e Tecnológico (CNPq) for the financial support to the research.

\section{Duplicação cromossômica em Lolium multiflorum Lam.}

Resumo - A duplicação cromossômica artificial de genótipos diploides de Lolium multiflorum (2n=2x=14) é importante para melhoristas, pois visa aumentar a expressão de caracteres de interesse agronômico. O objetivo deste trabalho foi obter plantas poliploides de L. multiflorum de populações locais diploides para explorar a adaptação e verificação futura dos efeitos da poliploidia sobre as características agronômicas. Plântulas foram imersas em diferentes soluções de colchicina, com tempo de exposição de 3 e 24 horas. A determinação da ploidia foi feita pelo conteúdo de DNA e certificada pela contagem cromossômica. As plantas efetivamente confirmadas como tetraploides foram mantidas em casa de vegetação e, no florescimento, foi feita a avaliação da viabilidade polínica e colheita sementes para avaliar a estabilidade das progênies. A porcentagem de poliploides obtidos foi de $20 \%$. A viabilidade polínica das plantas tetraploidizadas variou de 58\% a 69\%. As plantas tetraploides obtidas geraram 164 progênies, das quais 109 apresentaram conteúdo de DNA compatível com o nível tetraploide, demonstrando estabilidade da duplicação cromossômica na geração filial.

Palavras-chave: Poliploidização, tetraploide, gramíneas forrageiras, melhoramento de plantas.

\section{REFERENCES}

Allum JF, Bringloe DH and Roberts AV (2007) Chromosome doubling in a Rosa rugosa Thunb. hybrid by exposure of in vitro nodes to oryzalin: the effects of node length, oryzalin concentration and exposure time. Plant Cell Report 26: 1977-1984.

Barbosa S, Davide LC, Pereira AV and Abreu JC (2007) Duplicação cromossômica de híbridos triploides de capim elefante e milheto. Bragantia 66: 365-372.
Campos JMS, Davide LC, Salgado CC, Santos FC, Costa P N, Silva PS, Alves CCS, Viccini LF and Pereira AV (2009) In vitro induction of hexaploid plants from triploid hybrids of Pennisetum purpureum and Pennisetum glaucum. Plant Breeding 128: 101-104.

Castro CM, Oliveira AC and Carvalho FIF (2003) Changes in allele frequencies in colchicine-treated ryegrass populations assessed with RAPD markers. Revista Brasileira de Agrociência 9: 107-112.

Dhooghe E, Van Laere EK, Eeckhaut T, Leus L and Van Huylenbroeck J (2011) Mitotic chromosome doubling of plant tissues in vitro. Plant 
Cell, Tissue and Organ Culture 104: 359-373.

Dolezel J (1997) Application of flow cytometry for the study of plants genomes. Journal of Applied Genetics 38: 285-302.

Greplova M, Polzerova H and Domkarova J (2009) Intra-and interspecific crosses of Solanum materials after mitotic polyploidization in vitro. Plant Breeding 128: 651-657.

Hamill S, Smith M and Dodd W (1992) In vitro induction of banana autotetraploids by colchicine treatment of micropropagated diploids. Australian Journal of Botany 40: 887-896.

Humphreys M, Feuerstein U, Vandewalle M and Baert J (2010) Ryegrasses. In Boller B, Posselt UK, Veronesi F (eds.) Handbook of plant breeding: fodder crops and amenity grasses. Springer, New York, p. 211-260.

Ishigaki G, Gondo T, Suenaga K and Akashi R (2009) Induction of tetraploid ruzigrass (Brachiaria ruziziensis) plants by colchicine treatment of in vitro multiple-shoot clumps and seedlings. Grassland Science 55: 164-170.

Jones ML and Humphreys MO (1993) Progress in breeding interspecific hybrid ryegrasses. Grass and Forage Science 48: 18-25.

Nair RM (2004) Developing tetraploid perennial ryegrass (Lolium perenne L.) populations. New Zealand Journal of Agricultural Research 47: 45-49.

Nunes RC, Bustamante FO, Techio VH and Mittelmann A (2012) Morphology and pollen viability of Lolium multiflorum Lam. Ciência e Agrotecnologia 36: 180-188.

Pasakinskiene I (2000) Culture of embryos and shoot tips for chromosome doubling in Lolium perenne and sterile hybrids between Lolium and Festuca. Plant Breeding 119: 185-187.

Pinheiro AA, Pozzobon MT, Valle CB, Penteado MIO and Carneiro VTC (2000) Duplication of the chromosome number of diploid Brachiaria brizantha plants using colchicine. Plant Cell Report 19: 274-278.

Quesenberry KH, Dampier JM, Lee YY, Smith RL and Aeuña CA (2010) Doubling the chromosome number of bahiagrass via tissue culture. Euphytica 175: 43-50.

Simioni C and Valle CB (2009) Chromosome duplication in Brachiaria (A. Rich.) Stapf allows intraspecific crosses. Crop Breeding and Applied Biotechnology 9: 328-333.

Souza-Kaneshima AM, Risso-Pascotto C, Pagliarini MS and Valle CB (2010) Meiotic behaviour in the first interspecific hybrids between Brachiaria brizantha and Brachiaria decumbens. Plant Breeding 129: 186-191.

Thomas H and Humphreys MO (1991) Progress and potential of interspecific hybrids of Lolium and Festuca. Journal of Agricultural Science 117: 1-8.

_Timbó_ALO, Souza PNC, Pereira RC,nunes JD, Pinto JEBP, Sobrinho FS and Davide LC (2014) Obtaining tetraploid plants of ruzigrass (Brachiaria ruziziensis). Revista Brasileira de Zootecnia 43: 127-131. 